Primljen / Received: 2.6.2016. Ispravljen / Corrected: 17.3.2017.

Prihvaćen / Accepted: 2.4.2017. Dostupno online / Available online: 10.5.2017.

\section{Composite columns made of concrete-filled hollow steel sections with embedded steel cores}

Authors:

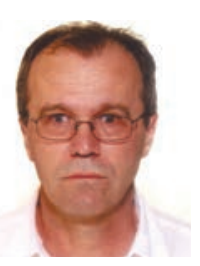

Prof. Darko Dujmović, PhD. CE

University of Zagreb

Faculty of Civil Engineering

Croatian Academy of Engineering

dujmovic@grad.hr

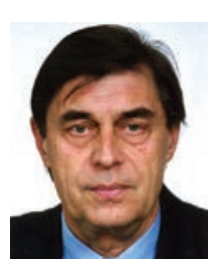

Prof. Boris Androić, PhD. CE

(Full Professor, retired)

Croatian Academy of Engineering

I.A. Projektiranje d.o.o., Croatia

androic@iaprojektiranje.com

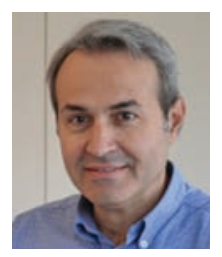

Dimitrios Tonis, PhD. CE

Spannverbund Bausysteme GmbH, Switzerland tonis@spannverbund.eu

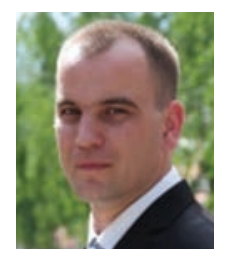

Ivan Lukačević, PhD. CE University of Zagreb

Faculty of Civil Engineering

ica@grad.hr
Subject review

Darko Dujmović, Boris Androić, Dimitrios Tonis, Ivan Lukačević

Composite columns made of concrete-filled hollow steel sections with embedded steel cores

A review of current surveys related to composite columns made of concrete filled tubes with embedded steel cores, known as Geilinger columns, is presented in the paper. Advantages and scope of application of this innovative composite column type are presented. Calculation of such columns according to the general method given in EN 1994-1-1, which is applied with known geometrical and structural imperfections, is explained. The simplified calculation method suitable for engineering practice is also considered. The aspects of fire resistance design are discussed.

Key words:

composite columns, embedded steel core, resistance, fire, load introduction, punching of slab

Pregledni rad

Darko Dujmović, Boris Androić, Dimitrios Tonis, Ivan Lukačević

\section{Spregnuti stupovi s poprečnim presjekom od šuplje cijevi ispunjene betonom i s umetnutom čeličnom jezgrom}

U radu je prikazan pregled suvremenih istraživanja spregnutih stupova izvedenih s cijevima ispunjenim betonom i s umetnutim čeličnim jezgrama, a poznatih su kao Geilinger stupovi. Prikazane su prednosti i područje primjene tih inovativnih tipova spregnutih stupova. Objašnjen je proračun ovakvih stupova prema općoj metodi danoj u EN 1994-1-1 koja se primjenjuje s poznatim geometrijskim i strukturnim nesavršenostima. Također je razmatrana pojednostavnjena metoda proračuna prikladna za inženjersku praksu. Obrazloženi su aspekti proračuna požarne otpornosti.

Ključne riječi:

spregnuti stupovi, umetnuta čelična jezgra, otpornost, požar, uvodenje opterećenja, proboj ploče

Übersichtsarbeit

Darko Dujmović, Boris Androić, Dimitrios Tonis, Ivan Lukačević

\section{Verbundstützen mit betongefülltem Hohlrohrquerschnitt und eingefügtem} Stahlkern

In dieser Arbeit wird ein Überblick aktueller Untersuchungen an Verbundstützen gegeben, die aus betongefüllten Rundrohren mit eingefügtem Stahlkern ausgeführt werden und als Geilinger-Stützen bekannt sind. Vorteile und Anwendungsbereiche dieses innovativen Verbundstützentyps werden dargestellt. Die Berechnung solcher Stützen gemäß dem allgemeinen Verfahren der Norm EN 1994-1-1, die bei bekannten geometrischen und strukturellen Imperfektionen anzuwenden ist, wird erläutert. Ebenso wird ein vereinfachtes, der Ingenieurspraxis angepasstes Berechnungsverfahren betrachtet. Die Berechnung des Brandwiderstands betreffende Aspekte werden dargelegt.

Schlüsselwörter:

Verbundstützen, eingefügter Stahlkern, Widerstand, Brand, Lasteinwirkung, Durchstanzen von Platten 


\section{Introduction}

The strongest arguments for an increasing use of composite columns include a great flexibility of application, significant costeffectiveness, short construction time, extraordinary load-bearing capacity, and impressive aesthetic appearance [1]. In addition to these facts, the development of modern dimensioning methods, and the application of European standards for structures, enable a reliable dimensioning of composite columns not merely in the "cold" state but also in the case of their exposure to fire load. The current objective relating to further development of composite columns is oriented toward design of increasingly economical structural solutions, and toward reduction of construction and installation costs.

A modern standardised design of composite columns is presented in this paper, with a special reference to the composite columns with embedded steel core, and their construction and dimensioning procedures, taking into account innovative load introduction principles as well as shearhead connection details enabling shear and moment transfer between reinforced concrete flat slabs and slender composite columns. Cross-sections of composite columns made of concrete filled tubes with embedded steel cores are shown in Figure 1. These types of columns are known as Geilinger columns [2], cf. Figure 2.
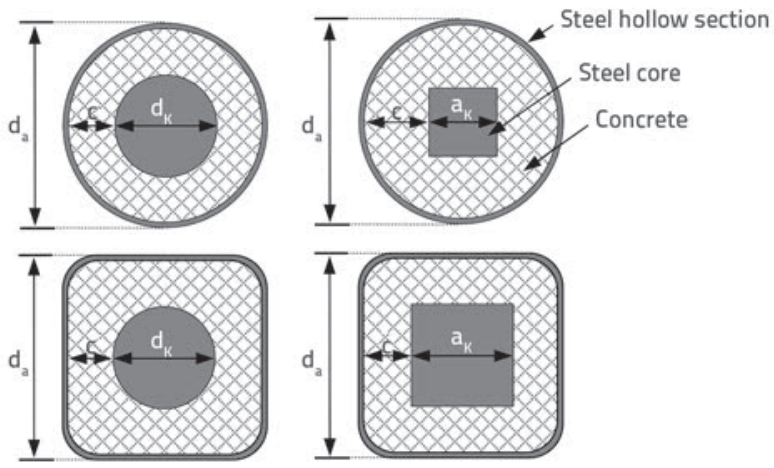

Figure 1. Cross-sections of composite columns made of concrete filled tubes with embedded steel cores

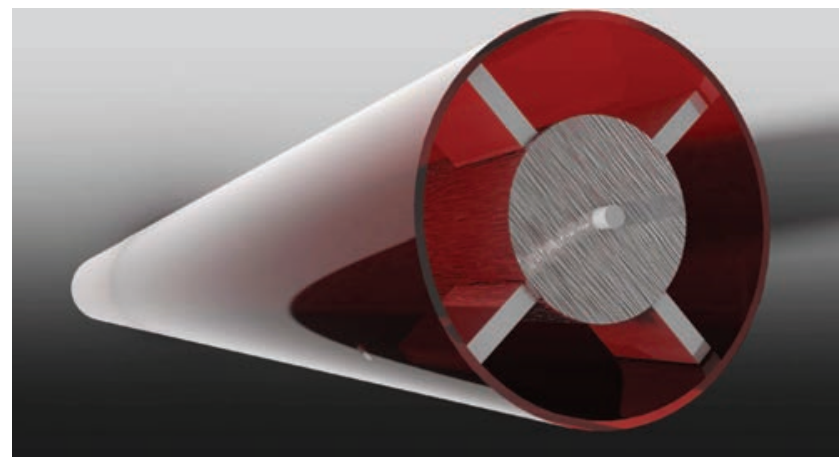

Figure 2. Composite column with embedded steel core, type Geilinger [3]

Geilinger columns consist of a central solid steel core ("embedded" steel core) in a concrete filled hollow steel section.
Spacer plates are used to secure the location of the steel core related to the hollow steel section. These plates are welded to both core and hollow section in the workshop. Concrete infill is normally cast at the jobsite.

However, despite doubly symmetrical cross-section, the Geilinger columns, or the columns with embedded steel core, cannot be calculated according to the simplified method given in EN 1994-1-1 [4]. Three materials in the composite section (steel tube, concrete, steel core) follow different non-linear relationships. Therefore, direct analysis of cross-sections is not possible. The reliability check is conducted using a procedure based on experimental and theoretical studies that is compliant with European standards. Main reasons lie in very high residual stresses in the steel core and in plastification of the steel core section with a very high plastic shape factor (the ratio of plastic section modulus to elastic section modulus) [5].

\section{Application of composite columns with embedded steel core}

As for the use of composite columns with embedded steel core, three major arguments can be mentioned: large slenderness slenderness, favourable behaviour in case of fire, and rapid assembly. A quality comparison of different column crosssections is presented in Figure 3 for the same load conditions.

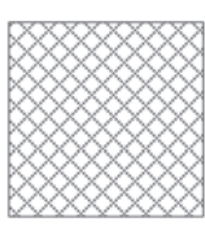

Composite column with fully
concrete-encased $\mathrm{H}$-section

Reinforced concrete column

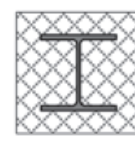



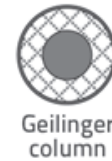

column
Figure 3. Comparison of different cross-sections of columns at the same load conditions

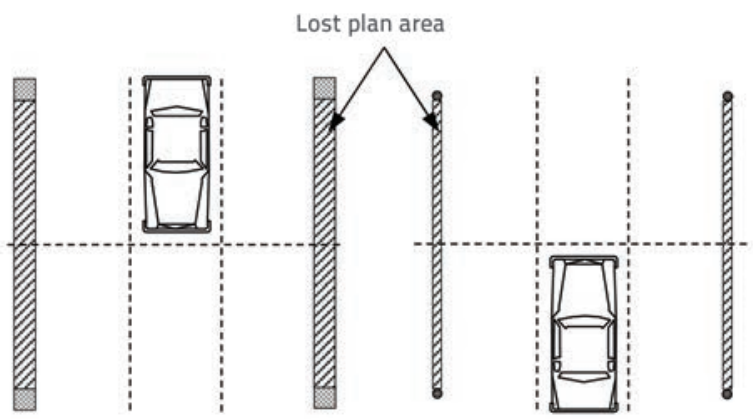

Figure 4. Lost plan areas of a building due to different cross-sectional dimensions of columns

As shown in Figure 3, outer dimensions of the columns with embedded steel core are approximately half the size of concrete columns. Also, the area of their cross sections is about one-fourth of the cross-sectional area of concrete columns. 
Regardless of the fact that the slenderness of columns has its price, significant savings in the plan area of a building can ultimately be achieved. Thus, for instance, by applying columns of small cross-sectional dimensions according to [2], the area lost between their overall dimensions is reduced as shown in Figure 4.

The idea of slenderness can also be related to an aesthetic impression resulting from small cross-sectional dimensions, as shown in Figures 5, 6 and 7.

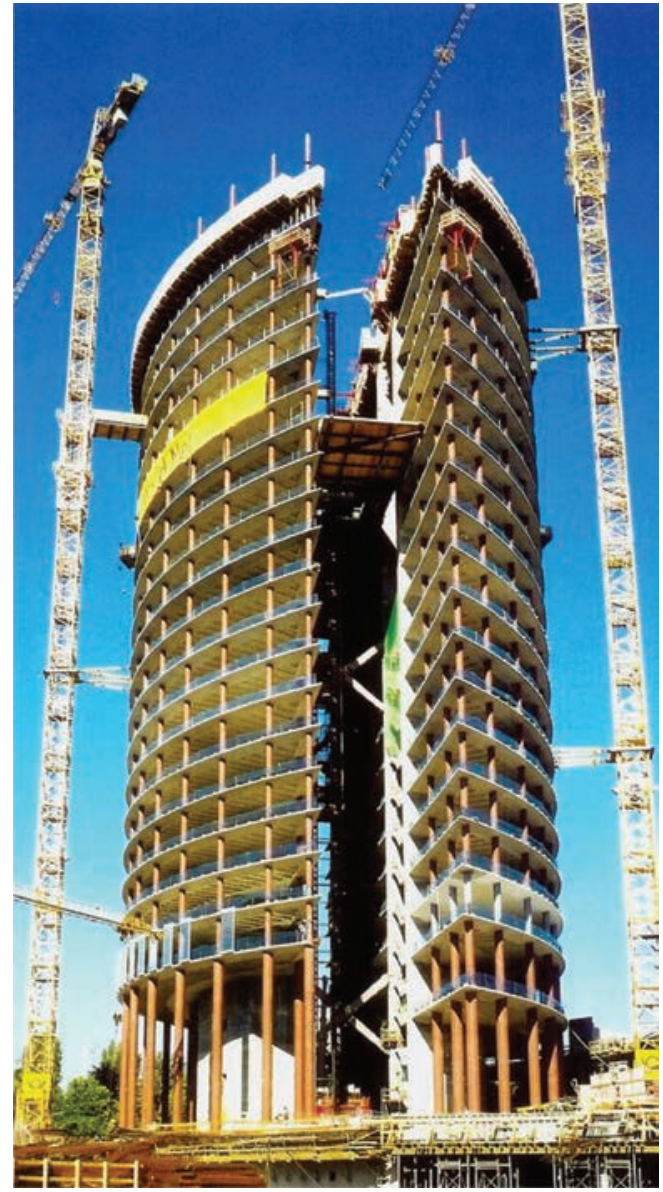

Figure 5. Posttower, Bonn: 42 floors, $\mathrm{N}_{\mathrm{Ed}, \max }=28000 \mathrm{kN}$ GeilingerStützen ${ }^{\circledR} \emptyset 762 \mathrm{~mm}-\emptyset 406 \mathrm{~mm}$

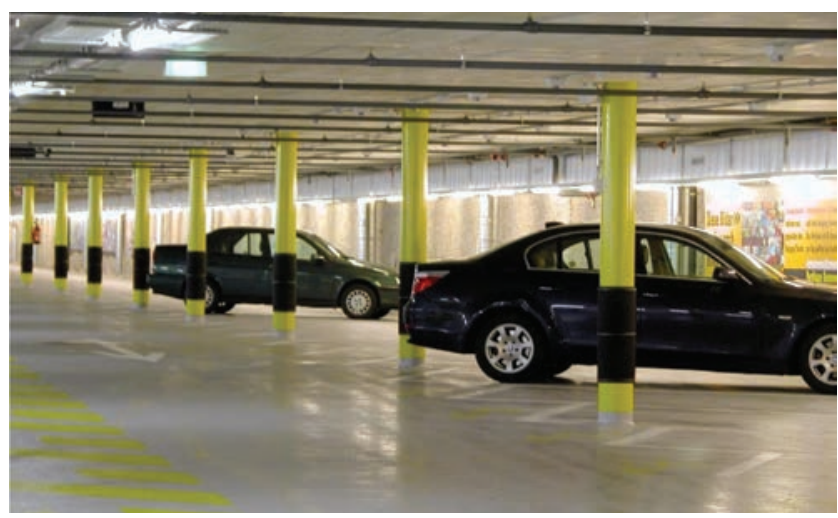

Figure 6. Gessnerallee Carpark in Zurich

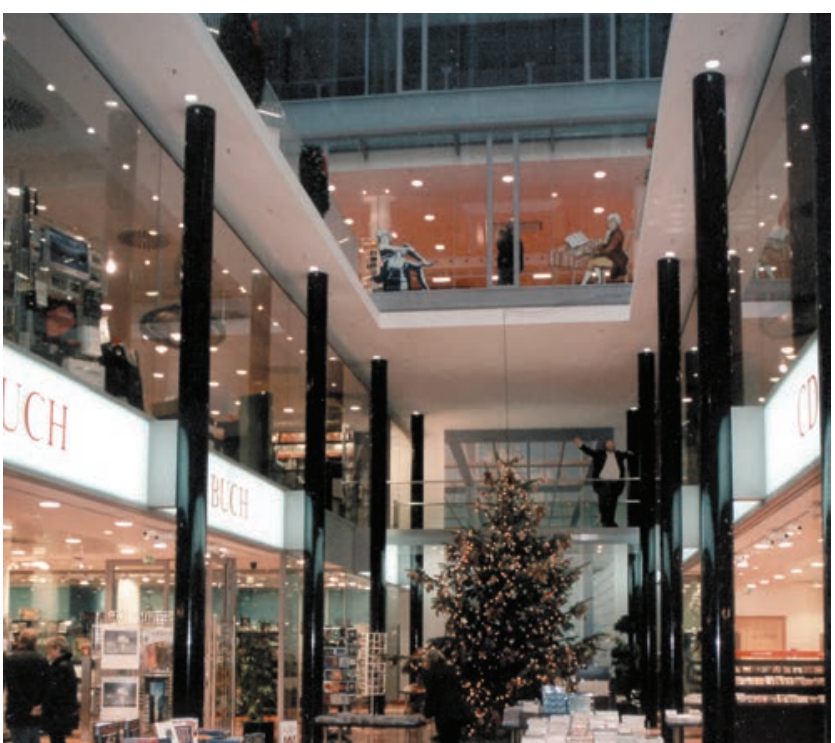

Figure 7. Dussmann shopping centre, Berlin Geilinger-Stützen ${ }^{\circledR} \emptyset 273$ $\mathrm{mm}$

Despite their small cross-sectional dimensions, composite columns made of concrete filled tubes with embedded steel core exhibit a favourable fire behaviour because the concrete contained in the tube slows down the heating of the entire cross section. High fire resistance classes can therefore be achieved. It is fair to say that, thanks to this feature and other favourable characteristics, these columns belong to the class of "robust structural elements" [6]. This is further supported by the fact that no intumescent coatings are applied. Such coatings are susceptible to damage. Their fire protection capability is lost if they are subjected to impacts or other mechanical damage.

\section{Composite column calculation methods}

The calculation of composite columns is based solely on the second order theory where two different methods can be applied according to EN 1994-1-1 [4]. The verification based on the first calculation method is carried out according to the second order theory, and focuses on geometric and structural imperfections, local instabilities, influences of concrete cracking, material non-linearities, as well as on the creep and shrinkage of concrete. In the EN 1994-1-1 [4] this method is known as the "general method" and is applied for composite columns of nonsymmetrical and uneven cross-section along the column axis. The second composite-column calculation method relies on the introduction of an equivalent geometric imperfection, and is referred to as the "simplified method". It is applied for composite columns characterized by double-symmetrical and uniform cross-section along the column axis, limited slenderness ratio $(\bar{\lambda} \leq 2.0)$, fully encased steel section of limited concrete-cover thickness, longitudinal reinforcement that may be used in calculation of no more than $6 \%$ of the concrete area, and the depth to width ratio of the composite cross-section ranging 
from 0.2 to 5.0. Examples of composite column calculation according to this method are given in [7].

The steel portion of the cross-section is limited in both calculation methods $(0.2<\delta<0.9)$.

The development of new types of composite columns has led to cross-sections that cannot be dimensioned according to simplified (linear) methods. In such cases, the calculation has to be made according to the general method. That method is based on the non-linear analysis that takes into account material and geometrical non-linearities. It should be noted that the general method proposed in EN 1994-1-1 [4] is more a set of principles than a design method. The problem is how should a standardised reliability concept based on partial factors be adjusted and harmonized with the non-linear analysis [5].

The basic concept of non-linear analysis is based on mean values of material resistance $R_{m}$ as shown through $\sigma-\varepsilon$ relations. In addition, the resistance cannot be assessed directly taking into account different partial factors for different compositecolumn materials. Therefore, the overall safety factor $\gamma_{R}$ should be introduced for evaluating resistance of the system (common resistance of all materials or system capacity) [8]. In that case, design values for resistance of the steel hollow section, concrete, and steel core can be presented as follows:

$\mathrm{R}_{\mathrm{d}}=\frac{1}{\gamma_{\mathrm{R}}} \cdot \mathrm{R}_{\mathrm{m}}$

$R_{m}=\left[f_{y, a, R}, f_{y, a k, R}, f_{c, R}\right]$

where:

$f_{y, a R^{\prime}} f_{y, a k, R}$ - mean or nominal values of yield strength of the steel hollow section and steel core

$f_{c, R} \quad$ - mean or nominal value of concrete strength

$\gamma_{R} \quad$ - overall safety factor for system resistance (common resistance of all materials or system capacity).

The overall safety factor for system resistance $\gamma_{R}$ can be calculated according to the following expression [8]:

$\gamma_{\mathrm{R}}=\frac{\mathrm{R}_{\mathrm{pl}, \mathrm{m}}}{\mathrm{R}_{\mathrm{pl}, \mathrm{d}}}$

where:

$R_{p l, m}$ - the full plastic resistance of relevant critical cross-section calculated with mean or nominal values of material strength $R_{m^{\prime}}$ curve $A$ in Figure 8

$R_{p l, d}$ - design value of full plastic resistance of critical crosssection, curve $B$ in Figure 8.

The overall safety factor $\gamma_{R}$ is determined according to the procedure given in [5]. It can be determined using the interaction curve of the full plastic resistance of cross-section. The interaction curve $A$ shown in Figure 8 has to be calculated using mean or nominal material strength values.

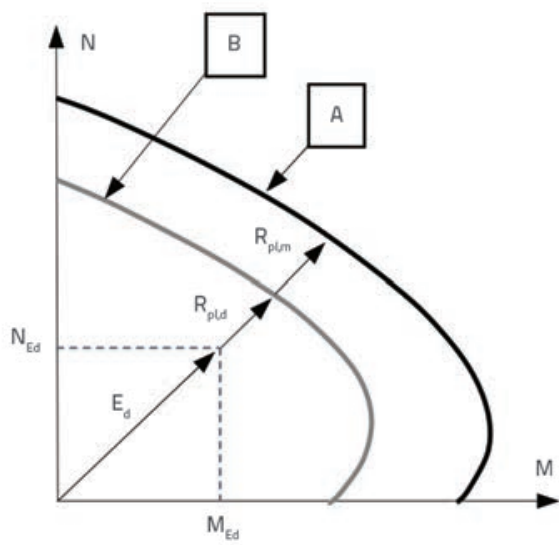

Figure 8. Determination of overall safety factor $\gamma_{R}$ [8]

In the case of testing, these values are the measured values obtained during the testing. However, nominal values can be adopted in the case without testing. The interaction curve $B$ has to be calculated using design values of material strength according to EN 1994-1-1 [4]. Accordingly, the partial factor 1,5 for concrete, 1,1 for structural steel and 1,15 for reinforcement have to be used for determining the interaction curve $B$ based on design values. As shown in Figure 8, for a given combination of design axial force $N_{E d}$ and design bending moment $M_{E d}$ the overall safety factor $\gamma_{R}$ is obtained from the ratio of the vectors $R_{p l, m}$ and $R_{p l, d^{*}}$ The general reliability verification format according to EN 1990 [9] is as follows:

$E_{d} \leq R_{d}=\frac{R_{m}}{\gamma_{R}}$

where:

$E_{d}$ - the design value of action effects

$R_{d}$ - the design value of resistance.

In the case of non-linear design of composite structures, the Eurocodes give no specific guidance for the reliability concept. Thus, the reliability check in the case of non-linear design is not carried out in accordance with expression (4). According to [10], the following condition should be verified:

$\lambda_{\mathrm{u}} \geq \gamma_{\mathrm{R}}$

In the above expression, $\lambda_{u}$ means the factor of load increase up to the ultimate system load. The factor $\lambda_{u}$ is obtained from the relationship between $F_{u, m}$ (load level at failure, this ultimate force can be obtained only by testing or by means of an advanced finite element method (FEM) with geometrical and material non-linear analyses i.e. GMNI) and the applied design load $F_{d}$ as follows:

$\lambda_{\mathrm{u}}=\frac{\mathrm{F}_{\mathrm{u}, \mathrm{m}}}{\mathrm{F}_{\mathrm{d}}}$

The application of reliability verification in the case of non-linear design of composite columns is shown in Figure 9. 


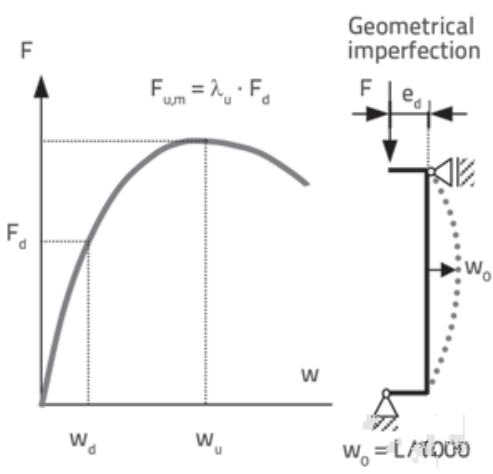

Figure 9. Reliability verification in case of non-linear design [10]

The requirements for application of the general method clearly point out that this method is not suitable for everyday engineering practice. Therefore, an appropriate computer software based on the method of finite elements is necessary. However, such software programs (e.g. ANSYS [11], ABAQUS [12]...) are, to a greater extent, still unavailable in practice. $A$ further difficulty results from the fact that the semi-probabilistic procedure (standardized procedure according to the European standard) is not suitable for use with nonlinear materials and for the procedure involving mean values of material resistance shown in $\sigma-\varepsilon$ diagrams.

For these reasons, the composite columns made of concrete filled tubes with embedded steel core are always designed and calculated using the general design method. In case of Geilinger columns, for everyday engineering practice, structural engineers can quickly determine column resistance for a given column length and size (section diameter or section width and height) by means of preliminary design tables for columns [13]. This is sufficient for the conceptual design phase. Final design, with detailed determination of steel core size, wall thickness of hollow section, concrete strength, etc. should be carried out using the general design method [3].

\section{Simplified method for calculation of composite columns with embedded steel core}

Composite columns with embedded steel core can not be calculated according to the simplified method given in EN 1994-1-1 [4]. Apart from limitations and restrictions related to the use of the simplified method (cf. Section 3), the main reasons include very high residual stresses in the steel core, and plastification of the steel core cross-section with a very high plastic shape factor.

Assuming that the limitations and restrictions mentioned in Section 3 are taken into account, the composite columns with embedded steel core could be calculated according to the simplified method given in EN 1994-1-1 provided that the structural imperfections are known. The buckling curve $a$ could be adopted in formal application of the simplified method for calculation of composite columns with embedded steel core. This assumption is based on a small steel core diameter. This means that in this case the residual stresses are negligible and the selection of the buckling curve $a$ can be considered justified. An accurate resistance calculation according to [5] shows that in this way the calculated resistance of composite column is significantly overestimated because a large diameter steel core has residual stresses that can reach the yielding strength. Due to this influence, a more unfavourable buckling curve $d$ must be used for the considered cross-section [5]. Residual stress influence results are shown in Figure 10.

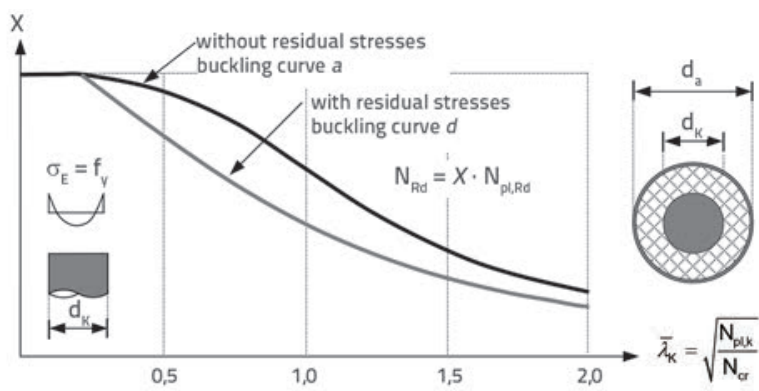

Figure 10. Influence of residual stresses [5]

Experimental research results [14] have shown that a largerdiameter embedded steel profile exhibits significant residual stresses. As composite columns with embedded steel core are made of large diameter steel cores, the buckling curve $d$ must be adopted.

If a composite column with embedded steel core, with known residual stresses of the embedded steel core, is subjected to an axial compressive force and bending moment, the resistance value obtained by applying the simplified method according to EN 1994-1-1 [4] is still less reliable compared to the general method. The reason is that the simplified method is based on the full plastic cross-section interaction curve of the composite section and an additional correction factor $\alpha_{M^{\prime}}$ which takes into account the difference between the plastic bending resistance and the non-linear bending resistance with strain limitation, cf. Figure 11. The difference between these resistances is that only a lesser part of the steel core cross-section is plastified in the case of the non-linear bending resistance with strain limitation for concrete, as shown in Figure 11.
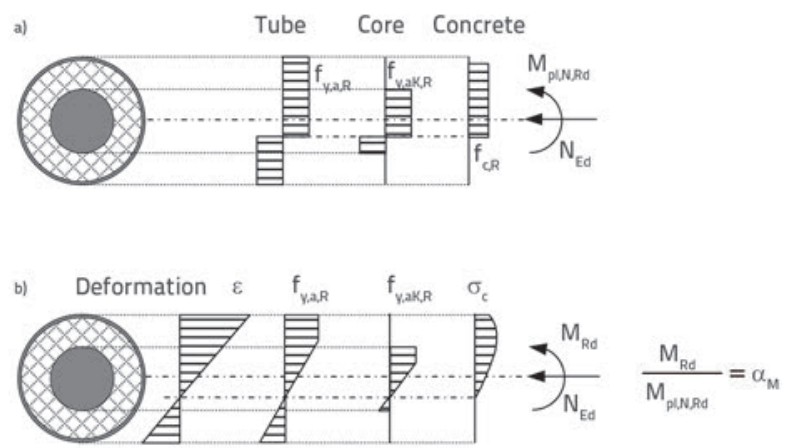

Figure 11. Difference between plastic bending resistance and nonlinear bending resistance with strain limitation [5] 
Research conducted in this area [5] shows that the correction factor $\alpha_{M}$ relating to Geilinger columns strongly depends on the ratio of the tube diameter, $d_{a^{\prime}}$ to the diameter of core profile, $d_{k}$ as well as on the steel grades of the hollow section and core profile. These dependencies should be taken into account when determining the factor $\alpha_{\mathrm{M}}$ for composite columns with embedded steel core.

A further problem lies in determining characteristic value of the steel core profile yield strength. The EN 10025-2 [15] gives characteristic yield strength values for steel products with thicknesses of up to $250 \mathrm{~mm}$ only, although these dimensions may be exceeded in the case of Geilinger columns.

All this shows that calculation of composite columns with embedded steel core according to the simplified procedure given in EN 1994-1-1 is not allowed. Consequently, resistance values for Geilinger type composite columns, as given in appropriate approvals [8] or in resistance calculation tables [13], are obtained according to the general method. Relevant assumptions for taking into account structural imperfections of composite columns with steel embedded core $[5,8,16]$ are shown in Figure 12.
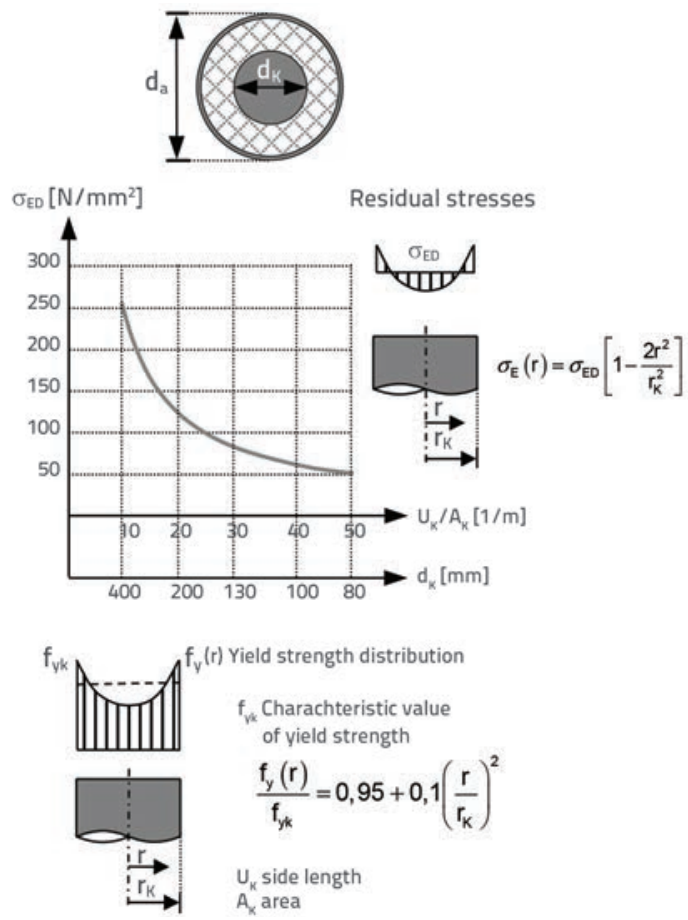

Figure 12. Calculation assumptions for taking into account structural imperfections of Geilinger columns [5]

Recent research efforts $[17,18]$ have been focusing on the application of such types of composite columns made of high strength steel and high strength concrete. As a result of this research, new models have been suggested for the determination of residual stress distribution taking into consideration steel grades, and the steel-core dimensions and manufacturing conditions. Such models could enable future application of calculation procedures based on the simplified method given in EN 1994-1-1. However, only the general calculation method can presently be applied due to the lack of code regulations and appropriate approvals.

\section{Fire resistance}

In accordance with fire-protection requirements, the structural fire design is performed according to EN 1994-1-2 [19]. It should be noted that EN 1994-1-2 provides a simple calculation procedure for composite columns with fully concrete-encased I-section, Figure 13.a or partially concrete-encased steel section, Figure 13.b, as well as for composite columns with concrete filled hollow sections, as shown in Figures 13.c and 13.d.
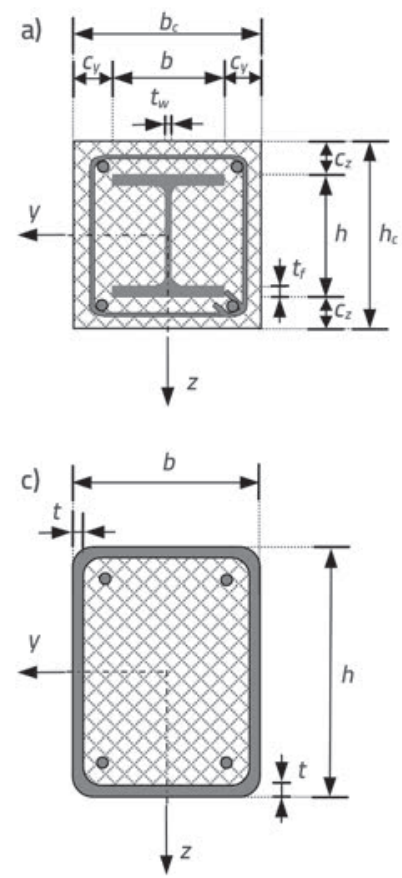

b)

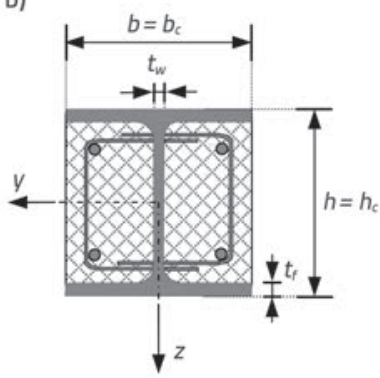

d)

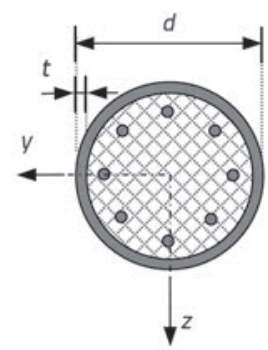

Figure 13. Composite-column cross sections that can be calculated according to simple calculation procedures presented in EN 1994-1-2

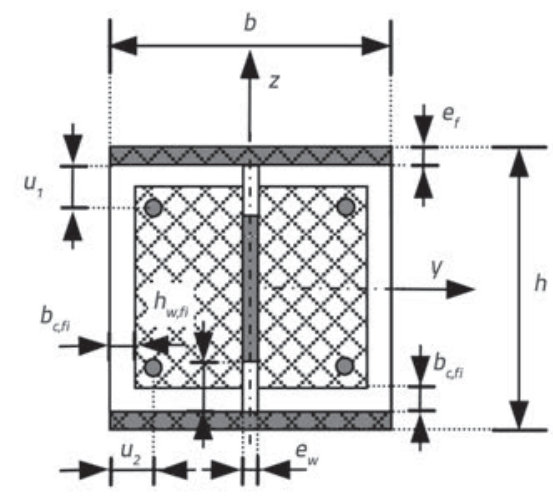

Figure 14. Reduced cross section for fire resistance calculation [19] 
Approximate procedures are given as tabulated data (level 1 design procedure, EN 1994-1-2, Clause 4.2) or as a simple calculation procedure (simple calculation model, level 2 design procedure, EN 1994-1-2, Clause 4.3). The simple calculation procedure is based on the cross-section reduced due to fire in which case each part of the cross-section, i.e. its resistance and stiffness, is reduced depending on its position in the cross section (model from Annex G, EN 1994-1-2, Figure 14).

A method for calculating the compressive strength of concrete filled tubular columns at elevated temperatures is proposed in EN 1994-1-2 [19], Annex H, cf. Figure 13.c and 13.d), and a simple equation is also given to account for the effect of eccentricity of axial load.

The method given in EN 1994-1-2, Annex H, defines conditions that must be satisfied for its application. The Annex $\mathrm{H}$ calculation method is assessed in research project presented in [20], and the author concludes that the Annex $\mathrm{H}$ method can be grossly inaccurate. Furthermore, a very detailed explanation of a more accurate fire-resistance calculation for composite columns is given in [21]. Composite columns with cross-sections shown in Figure 15 cannot be calculated according to the previously mentioned procedures from EN 1994-1-2.

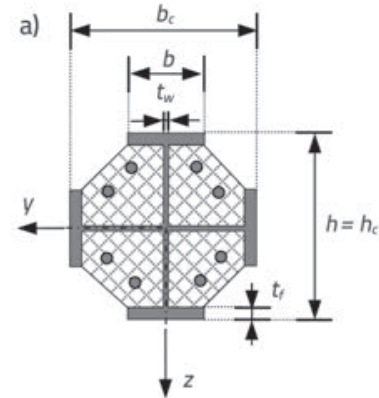

b)

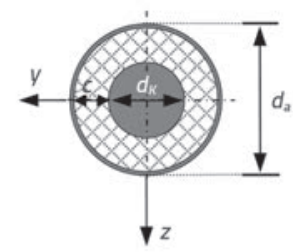

c)

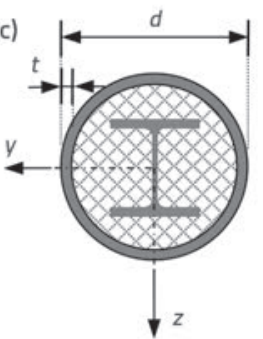

d)

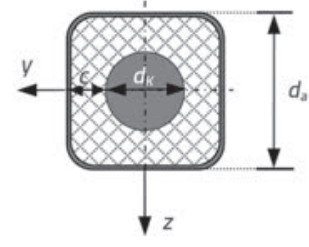

Figure 15. Composite column cross sections that cannot be calculated according to simple calculation procedures from EN 1994-1-2

Cross-sections shown in Figure 15 can be correctly calculated by means of exact calculation procedures only (general calculation procedure, advanced calculation methods, level 3 design method, EN 1994-1-2, Clause 4.4.) or by fire tests for columns. The thermal analysis of cross-section based on temperaturedependent material properties, with subsequent stress analysis for the overall structural system, is carried out in the mentioned exact calculation procedures. This calculation procedure is very comprehensive and highly complex and its implementation is possible only using powerful finite element software programs (e.g. ANSYS [11], ABAQUS [12]...). In the case of composite columns made of concrete filled tubes with embedded steel cores, main calculation difficulties to be taken into account during finite element modelling are [22]:

- implementation of constitutive laws, especially for concrete,

- modelling interface between concrete and steel,

- reproduction of actual boundary conditions,

- modelling of load introduction,

- approximation of structural and geometrical imperfections.

Furthermore, numerous fire tests must be conducted for application of these exact calculation procedures in order to compare numerical models with tests results. In this way, it is possible to define criteria for the evaluation of software applied in the analysis, and thus to make an objective comparison of obtained results. In case of Geilinger columns, preliminary design tables for every day engineering use given in [13] (see Section 3) include fire resistance of Geilinger columns.

\section{Experiences from practice}

For example, steel cores for Geilinger columns range from 40 $\mathrm{mm}$ to $600 \mathrm{~mm}$ in diameter. According to European standards (Eurocodes), the yield strength reductions must be considered for steel profiles with thickness in excess of $40 \mathrm{~mm}$. However, as mentioned before, this rule applies only to thickness values of up to $250 \mathrm{~mm}$, EN 10025-2 [15]. In any case, taking into consideration the criteria given in EN 10204 [23], Clause 3.1, minimum yield strength values must be ensured for basic material. Similarly, structural elements needed to introduce load into a composite column are connected to the steel core by welding. According to welding requirements, at least subgrade $\mathrm{J} 2$ must be used for steel core [2]. This points to the importance of undertaking appropriate quality control and quality assurance for embedded steel cores. Experiences from practice given in [2] points to the following problems:

- Larger-diameter steel core profiles are in many cases manufactured in the countries outside of the EU. In spite of the test certificate documentation stating a satisfactory quality, the real quality is unsatisfactory.

- Similarly, the steel core profiles manufactured in the EU countries only nominally satisfy yield strength and toughness values set forth in the test certificate documentation. It happens sometimes that the samples are normalised before testing, so the values of mechanical characteristics contained in the submitted test certificates do not comply with the real values of steel core profiles.

- Sometimes the suppliers of steel core profiles deliver the test certificate documentation at a later date when the profiles have already been installed. In order to avoid this situation, the acceptance of profiles must be made by inspection service at the supplier's facility. It is not a rare case that only one- third of test samples satisfy the prescribed quality at the time of material acceptance. 
All these reasons confirm that it is necessary, for the sake of safety, to entrust the execution and erection of the composite columns made of concrete filled tubes with embedded steel core to specialised companies. In addition, it should be noted that Geilinger composite columns are proprietary products of Spannverbund GmbH / Spannverbund Bausysteme GmbH. They need specialist design input which is in every particular case provided by this firm, including provision of structural details for load transfer between the column head / column base and the connection of concrete structure (slab, beam or wall).

\section{Load introduction}

Numerous studies have been conducted to explain and create a model of load introduction into composite columns [24-26]. The shear resistance between the steel core profile and concrete, and between the steel tube and concrete, can be ensured only by shear strength or, additionally, by means of shear connectors. The introduction of load into the Geilinger column can be ensured in one of three ways as shown in Figure 16.

Load introduction shown in Figure 16.a is achieved through the cap plate welded on the column top where it is essential that the core is in a continuous contact with concrete. In the case shown in Figure 16.b, the load introduction is achieved solely through steel core. In case of detail b) from Figure 16 the isolated steel core is extremely sensitive to fire and it should be protected by the fire resistant ceiling or by similar means. And, finally, in the case shown in Figure 16.c, the load introduction is achieved through the steel core and concrete slab.

In case of load introduction shown in Figure 16.a, it is only important that the joint between the steel cap plate and concrete is in continuous pressure contact considering concrete creep and shrinkage. In this case of load introduction, it is not necessary to carry out a verification - except with regard to plate thickness. However, in cases shown in Figures 16.b and 16.c, such verification is necessary, and it will be explained in greater detail.

\subsection{Load introduction through steel core}

In case when load is introduced into the composite column through steel core, the resistance verification must be made in the load introduction length $L_{E}$ for two critical surfaces. The first surface relates to the steel core and concrete interface, while the second one relates to the concrete and steel tube interface. The verification reads as follows:

$\frac{V_{L, E d}}{V_{L, R d}} \leq 1,0$

In the Exp. (7), $V_{L, E d}$ concerns the design effects of longitudinal shear force in relevant critical surfaces, while $V_{L, R d}$ relates to the design longitudinal shear resistance. The design length of load introduction into the composite column is denoted by $L_{E}$ and reads as follows [8]:

$L_{E}=2,5 \cdot d_{a} \leq \frac{1}{3} \cdot L$

In the Exp. (8), $d_{a}$ is the outer diameter of the composite column cross-section, and $L$ is the column length. Figure 17 shows load introduction into the composite column through steel core. Design values of longitudinal shear forces can be obtained according to following expressions for two critical surfaces:

a) Surface steel core - concrete:

$V_{L, E d}=N_{E d} \cdot \frac{N_{p l, c, d}+N_{p, a, d}}{N_{p l, R d}}$

b) Surface concrete - steel tube

$\mathrm{V}_{\mathrm{L}, \mathrm{Ed}}=\mathrm{N}_{\mathrm{Ed}} \cdot \frac{\mathrm{N}_{\mathrm{pl}, \mathrm{a}, \mathrm{d}}}{\mathrm{N}_{\mathrm{pl}, \mathrm{Rd}}}$

In Exps. (9) and (10):
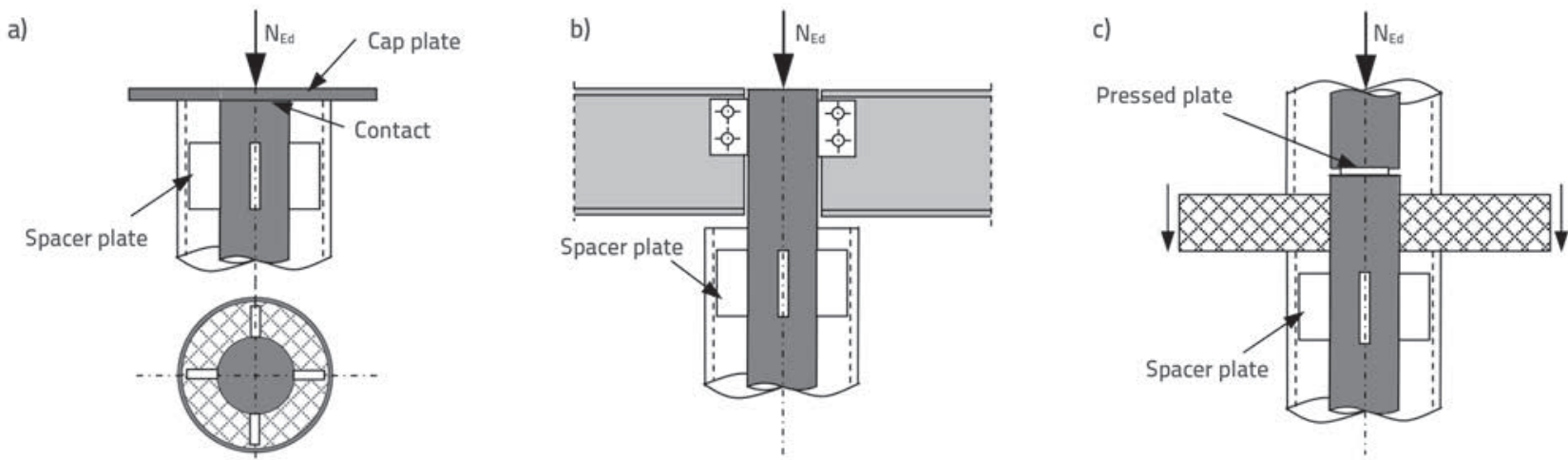

Figure 16. Possibilities of load introduction into Geilinger column 
$N_{E d} \quad$ - design value of axial force introduced into the steel core,

$N_{p l, R d}$ - design value of full plastic resistance of composite column cross-section: $N_{p l, R d}=N_{p l, a, d}+N_{p l, c, d}+N_{p l, a k, d}$

$N_{p l a, d}$ - design value of full plastic resistance of steel tube cross-section

$N_{p l, c, d}$ - design value of full plastic resistance of concrete crosssection

$N_{p l, a k, d}$ - design value of full plastic resistance of steel core crosssection.

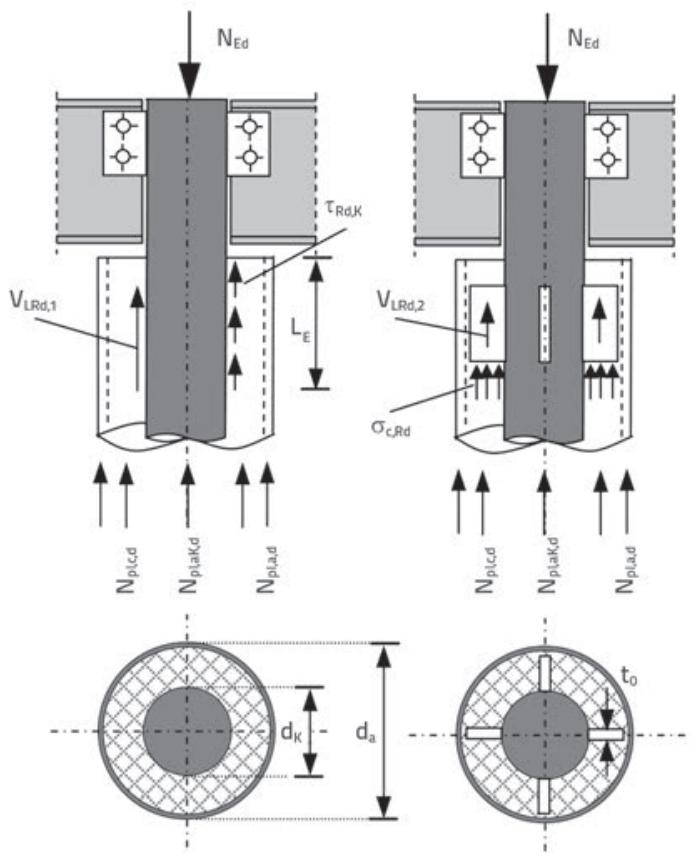

Figure 17. Load introduction through steel core

The calculation of the critical surface steel core-concrete resistance is carried out in the following way. The shear resistance in the length $L_{E}$ is achieved from two parts. The first part $V_{L R d, 1}$ provides resistance through the shear strength $\tau_{R d, K^{L}}$ while the other part $V_{L, R d, 2}$ provides resistance through the spacer plate in contact with concrete. Thus, the total design shear resistance is:

$\mathrm{V}_{\mathrm{L}, \mathrm{Rd}}=\mathrm{V}_{\mathrm{L}, \mathrm{Rd}, 1}+\mathrm{V}_{\mathrm{L}, \mathrm{Rd}, 2}$

The values from Exp. (11) are obtained as follows:

$\mathrm{V}_{\mathrm{L}, \mathrm{Rd}, 1}=\pi \cdot \mathrm{d}_{\mathrm{K}} \cdot \mathrm{L}_{\mathrm{E}} \cdot \tau_{\mathrm{Rd}, \mathrm{K}}$

$\mathrm{V}_{\mathrm{L}, \mathrm{Rd}, 2}=\mathrm{A}_{\mathrm{D}} \cdot \sigma_{\mathrm{c}, \mathrm{Rd}}$

In the Exps. (12) and (13), $A_{D}$ denotes the cross-sectional area of the spacer plate, and $\sigma_{c, R d}$ represents the local design strength of concrete under the spacer plate, and $\tau_{R d, K}$ is the design value of shear strength at the steel core - concrete surface. The values of $\sigma_{c, R d}$ and $\tau_{R d, K}$ can be determined according to EN 1994-1-1, Clause 6.7.4 [4] or - in case of Geilinger columns - according to design recommendations given in [8].

The calculation of the longitudinal shear resistance for the second critical concrete - steel tube surface is determined by:

$\mathrm{V}_{\mathrm{L}, \mathrm{Rd}}=\mathrm{L}_{\mathrm{E}} \cdot \pi \cdot\left(\mathrm{d}_{\mathrm{a}}-2 \cdot \mathrm{t}_{\mathrm{R}}\right) \cdot \tau_{\mathrm{Rd}, \mathrm{R}}$

In the Exp. (14) $t_{R}$ denotes the wall thickness of the steel tube and $\tau_{R d, R}$ is the design value of the shear strength at the concrete - steel tube surface. The value of $\tau_{R d, R}$ can be determined according to EN 1994-1-1 Clause 6.7.4 [4] or - in case of Geilinger columns - according to design recommendations given in [8].

\subsection{Load introduction through steel core and concrete slab}

Load introduction through steel core and concrete slab is shown in Figure 18.
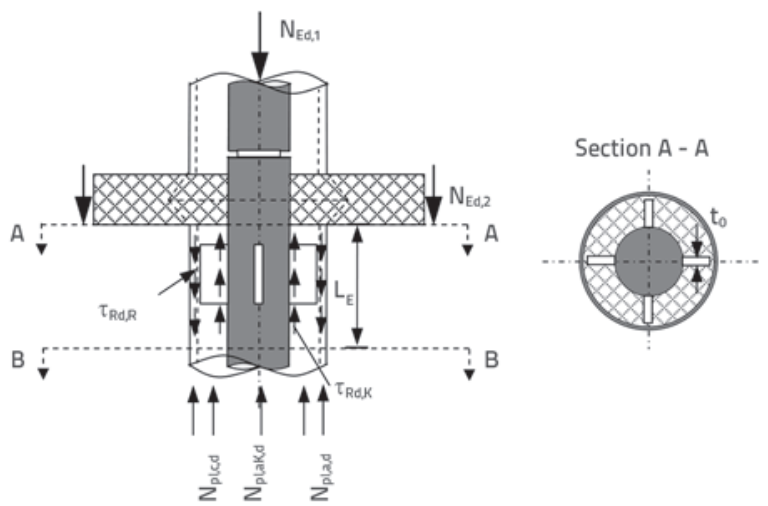

Figure 18. Load introduction through steel core and concrete slab

Design values of longitudinal shear forces can be determined for two critical surfaces according to the following expressions:

a) Surface steel core - concrete

$V_{L, E d}=\frac{N_{E d, 1}+N_{E d, 2}}{N_{p l, R d}} \cdot N_{p l, a K, d}-\frac{N_{E d, 1}}{N_{p l, a K, d}+N_{p l, c, d}} \cdot N_{p l, a K, d}$

b) Surface concrete - steel tube

$\mathrm{V}_{\mathrm{L}, \mathrm{Ed}}=\frac{\mathrm{N}_{\mathrm{Ed}, 1}+\mathrm{N}_{\mathrm{Ed}, 2}}{\mathrm{~N}_{\mathrm{pl}, \mathrm{Rd}}} \cdot \mathrm{N}_{\mathrm{pl}, \mathrm{a}, \mathrm{d}}$

In Exps. (15) and (16):

$N_{p l, R d}$ - design value of full plastic resistance of composite column cross-section

$N_{p l, R d}=N_{p l, a, d}+N_{p l, c, d}+N_{p l, a k, d^{\prime}}$ 
$N_{p l, a, d}$ - design value of full plastic resistance of steel tube cross-section

$N_{p l, c, d}$ - design value of full plastic resistance of concrete crosssection

$N_{p l a k, d}$ - design value of full plastic resistance of steel core crosssection.

In case of load introduction through steel core and concrete slab, the load from the slab $N_{E d, 2}$ is directly introduced into the concrete part of the column section (the steel tube crosssection is neglected). The load $N_{E d, 1}$ from the upper columns should additionally be taken into account. In the section A-A Figure 18, the portions of the action effects for steel core $N_{E d, a k, A}$ and concrete slab $N_{E d, c, A}$ should be determined.

The verification of the design longitudinal shear resistance is the same as set forth in Section 7.1. It is only necessary to determine the design longitudinal shear force from the difference of the axial forces between the section $A-A$ and the section at the end of the length of load introduction, section B-B from Figure 18.

\section{Slab punching}

In the case of slender columns and reinforced concrete slabs the slab punching may pose a special problem. This problem may be a decisive criterion for selection of the column and its connection to the slab. If Geilinger columns are selected, the slab connection to the column and the slab punching problem can be structurally solved by means of a steel shearhead (made of square grillages of channel or I sections) at the top of the column, using the so-called Geilinger-Europilz system [2730], as shown in Figure 19.a. Additional increase of punching resistance can be achieved by combining the steel shearhead with studrails, Figure 19. b, [2-3, 28, 31-33].

One of significant advantages of Geilinger-Europilz systems is the substantially increased ductility that allows larger rotation capacity. This capacity enables effective redistribution of bending moments and internal forces in the flat slab system.
More detailed rules for the dimensioning and application of Geilinger-Europilz steel shearheads are given in [27] and shown in Figure 19.a). The dimensioning and application of the system - combination of steel shearhead with studrails (cf. Figure 19.b) - are very extensively explained in [31, 32]. It should be noted that Geilinger-Europilz shearheads - just like Geilinger columns - are proprietary products of Spannverbund GmbH / Spannverbund Bausysteme GmbH and need specialist design input.

\section{Conclusion}

Composite columns combine steel and concrete so as to utilise the advantages of both materials and avoid their weaker sides. They are characterized by large slenderness and greater load bearing capacity compared to reinforced concrete columns. These features are particularly pronounced in the case of columns made of concrete-filled hollow steel sections and embedded steel cores.

Composite columns made of concrete filled tubes with embedded steel cores, presented in this paper, are not covered by the existing regulations for composite structures. Most composite columns in practical use meet design requirements for the simplified method as given in EN 1994-1-1. However, due to the reasons stated in this paper, the design of columns made of concrete-filled hollow steel sections and embedded steel cores can not be made according to the simplified method. The reason is that the steel core has high residual stresses, and the column cross-section is of specific geometry. Calculation procedure based on the simplified method would be possible only after the models for determining residual stress distribution depending on steel grades, steel core dimensions, and relevant manufacturing conditions, are developed.

At the present time, the calculation of composite columns made of concrete filled tubes with embedded steel cores is always carried out using the general design method. The concept of calculation of such columns according to the general method a)

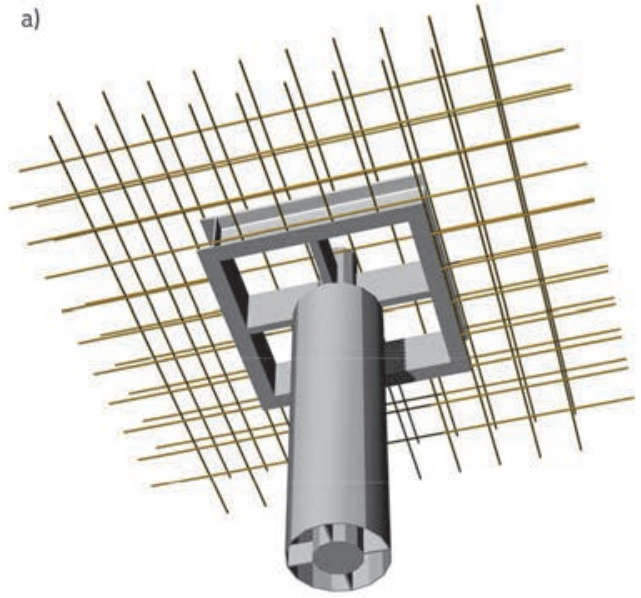

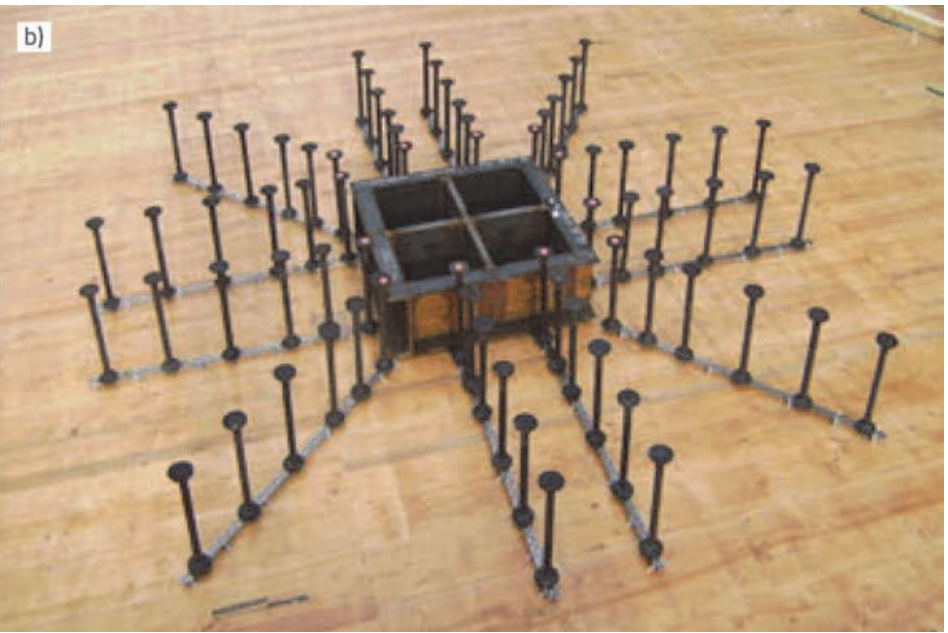

Figure 19. Structural details - Geilinger Europilz systems: a) Geilinger-Europilz steel shearhead; b) combination of steel shearhead with studrails 
given in EN 1994-1-1 is explained. This method can be applied with known geometrical and structural imperfections. However, it is not suitable for the every day engineering practice. Thus, preliminary design tables with load bearing capacity for a variety of column lengths and column sizes should be applied in case of Geilinger composite columns.

The stated calculation methods, the simplified method, and the general method according to EN 1994-1-1, are the basis for calculation methods relating to columns exposed to fire. Features of methods for calculating fire resistance of composite columns according to EN 1994-1-2 are listed in the paper. However, simplified calculation methods must not be applied in the case of composite columns made of concrete-filled hollow steel sections and embedded steel cores. These column types can be correctly calculated only with exact design procedures or by fire tests for columns.

Structural details for load introduction are considered in greater detail due to their significance for integration of columns into the structural system. Innovative structural details that increase resistance to slab punching failure are also presented.

\section{REFERENCES}

[1] Androić, B., Dujmović, D., Lukačević, I.: Projektiranje spregnutih konstrukcija prema Eurocode 4, prvo izdanje, I.A. Projektiranje, Zagreb, 2012.

[2] Tonis, D.: Verbundstützen und Geilinger-Stützen Konstruktion Bemessungsaspekte, Beispiele, SIA Dokumentation D 0219, Stahl-Beton-Verbund im Hochbau Dauerhafte und innovative Tragwerke, 2007.

[3] Spannverbund bausysteme Gmbh, Spannverbund GmbH, http:// www.spannverbund.eu/

[4] EN 1994-1-1 (2004) + AC (2009): Eurocode 4: Design of composite steel and concrete structures, Part 1-1: General rules and rules for buildings, CEN European Committee for Standardization.

[5] Hanswille, G.: Die Bemessung von Stahlverbundstützen nach nationalen und EU-Regeln, Der Prüfingenieur, 22 (2003), pp. 1731.

[6] Fontana, M.: Brandsicherheit von Verbundtragwerken: Stahlbau Kalender 2000; Ernst \& Sohn Verlag, Berlin 2000.

[7] Dujmović, D., Androić, B., Lukačević, I.: Composite Structures according to Eurocode 4: Worked Examples, Ernst \& Sohn, Berlin 2015.

[8] Allgemeine bauaufsichtliche Zulassung - Zullassungnummer: Z-26.3- 60 (2014): Verbundstütze mit Kernprofil System Geilinger-Stütze, Deutsches Institut für Bautechnik, Berlin. (On behalf of Spannverbund $\mathrm{GmbH}$, not publicly available).

[9] EN 1990 (2002) + A1 (2005) + A1:2005/AC (2010): Eurocode 0 : Basis of structural design, CEN European Committee for Standardization.

[10] Hanswille, G. Schäfer, M., Bergmann, R.: Stahlbau-normen - Verbundtragwerke aus Stahl und Beton - Bemessung und Konstruktion; Kommentar zu DIN 18800-5:2007-03: StahlbauKalender 2010, Ernst \& Sohn, Berlin 2010.

[11] ANSYS User's Manual (Version 14.0). Houston, Swanson Analysis Systems Inc. 2011.

[12] ABAQUS, User's Manual, Version 6.12, Dassault Systèmes Simulia Corp., 2012

[13] Vorbemessungstabellen: Geilinger-Stütze, Spannverbund bausysteme Gmbh, http://www.spannverbund.eu

[14] Hanswille, G., Bergmann, R.: Neuere Untersuchungen zur Bemessung und Lasteinleitung von ausbetonierten HohlprofilVerbundstützen. Festschrift Prof.F. Tschemmernegg, Institut für Stahlbau, Holzbau und Mischbautechnologie, Innsbruck (Österreich) 1999.
[15] EN 10025-2 (2004): Hot rolled products of structural steels - Part 2: Technical delivery conditions for non-alloy structural steels, CEN European Committee for Standardization.

[16] Roik, K., Schaumann, P.: Tragverhalten von Vollprofilstützen Fliessgrenzenverteilung an Vollprofilquerschnitten; Institut für Konstruktiven Ingenierbau, Ruhr-Universität Bochum, Bochum, 1980.

[17] Lippes, M.: Zur Bemessung von Hohlprofil - Verbundstützen aus hochfesten Stählen und Betonen, Dissertation, Institut für Konstruktiven Ingenieurbau Bergische Universität Wuppertal, 2008.

[18] Hanswille, G., Lippes, M.: Einsatz von hochfesten Stählen und Betonen bei Hohlprofil-Verbundstützen, Stahlbau, 77 (2008) 4, 296-307.

[19] EN 1994-1-2 (2005) + AC (2008): Eurocode 4: Design of composite steel and concrete structures - Part 1-2: General rules - Structural fire design, CEN European Committee for Standardization.

[20] Renaud, C.: Improvement and extension of the simple calculation method for fire resistance of unprotected concrete filled hollow columns, CIDECT Research Project 15Q, Final Report, 2004.

[21] Wang, Y. C.: Design Guide for Concrete Filled Hot Finished Structural Hollow Section (SHS) Columns, In association with TATA Steel, 2014

[22] European Project FRISCC "Fire Resistance of Innovative and Slender Concrete Filled Tubular Composite Columns, RFSRCT_2012_00025, 2013

[23] EN 10204 (2004): Metallic products - Types of inspection documents, CEN European Committee for Standardization

[24] Hanswille, G., Bergmann, R.: Lasteinleitung von ausbetonierten Hohlprofil-Verbundstützen Festschrift Prof.F. Tschemmernegg, Institut für Stahlbau, Holzbau und Mischbautechnologie, Innsbruck (Österreich) 1999.

[25] Hanswille, G., Porsch, M.: Lasteinleitung von ausbetonierten Hohlprofil-Verbundstützen mit normal-und hochfesten Betonen. Studiengesellschaft Stahlanwendung e.V., Forschungsbericht (2003), pp. 487.

[26] Hanswille, G., Porsch, M.: Lasteinleitung bei ausbetonierten Hohlprofil-Verbundstützen, Stahlbau 73 (2004) 9, pp. 676-682, https://doi.org/10.1002/stab.200490171 
[27] Allgemeine bauaufsichtliche Zulassung - Zullassungnummer: Z-15.1-234(2011): Stahlpilz System Geilinger-Europilz als Durchstanzbewehrung in Platten, Deutsches Institut für Bautechnik, Berlin (On behalf of Spannverbund Bausysteme $\mathrm{GmbH}$, not publicly available).

[28] Bennett, D.: Innovations in concrete, First edition, Thomas Telford Publishing, London, 2002, https://doi.org/10.1680/iic.20054

[29] Frangi, T., Tonis, D., Muttoni, A.: Zur Bemessung innerer Stützenkopfverstärkungen aus Stahl, Schweizer Ingenieur und Architekt, (1997) 12, pp. 4.

[30] Muttoni, A.: Gutachten zum Durchstanzen von Flachdecken mit inneren Stützenkopfverstärkungen aus Stahl, 2006. (On behalf of Spannverbund Bausysteme GmbH, not publicly available).
[31] Muttoni, A.: Gutachten zur Bemessung von Halfen HDBDoppelkopfankern und Dübelleisten nach SIA 262, 2004. (On behalf of Halfen Swiss AG, not publicly available).

[32] Hegger, J., Beutel, R.: Gutachten zur Durchstanzbemessung der Kombination von Geilinger-Stahlpilz mit Halfen Doppelkopfankern nach SIA 262, 2005. (On behalf of Spannverbund Bausysteme $\mathrm{GmbH}$, not publicly available).

[33] Muttoni, A.: Gutachten zum Durchstanzen von Flachdecken mit inneren Stützenkopfverstärkungen und Doppelkopfanker als Durchstanzbewehrung, 2006. (On behalf of Spannverbund Bausysteme GmbH and Halfen Swiss AG, not publicly available). 